\title{
Plasma growth hormone and growth hormone-binding protein during development in the marsupial brushtail possum (Trichosurus vulpecula)
}

\author{
M C Saunders, R T Gemmell ${ }^{1}$, M J Waters and J D Curlewis \\ School of Biomedical Sciences, Department of Physiology and Pharmacology, The University of Queensland, Queensland 4072, Australia \\ ${ }^{1}$ Department of Anatomical Sciences, The University of Queensland, Queensland 4072, Australia \\ (Requests for offprints should be addressed to J D Curlewis; Email: j.curlewis@mailbox.uq.edu.au)
}

\begin{abstract}
Plasma concentrations of growth hormone $(\mathrm{GH})$ were measured in the brushtail possum (Trichosurus vulpecula) pouch young from 25 through to 198 days post-partum $(n=71)$. GH concentrations were highest early in pouch life (around $100 \mathrm{ng} / \mathrm{ml}$ ), and thereafter declined in an exponential fashion to reach adult concentrations $(10 \cdot 8 \pm 1 \cdot 8 \mathrm{ng} / \mathrm{ml} ; n=21)$ by approximately $121-145$ days post-partum, one to two months before the young is weaned. Growth hormone-binding protein (GHBP), which has been shown to modify the cellular actions of $\mathrm{GH}$ in eutherian mammals, was identified for the first time in a marsupial. Based on size exclusion gel filtration, possum GHBP had an estimated molecular mass of $\approx 65 \mathrm{kDa}$, similar to that identified in other mammalian species, and binding of ${ }^{125}$ I-labelled human GH (hGH) was displaced by excess hGH $(20 \mu \mathrm{g})$. An immunoprecipitation method, in which plasma GHBP was rendered polyethylene glycol precipitable with a monoclonal antibody to the rabbit GHBP/GH receptor (MAb 43) and
\end{abstract}

labelled with ${ }^{125} \mathrm{I}-\mathrm{hGH}$, was used to quantitate plasma GHBP by Scatchard analysis in the developing (pooled plasma samples) and adult (individual animals) possums. Binding affinity $\left(K_{\mathrm{a}}\right)$ values in pouch young aged between 45 and 54 and 144 and 153 days post-partum varied between $1 \cdot 0$ and $2 \cdot 4 \times 10^{9} / \mathrm{M}$, which was slightly higher than that in adult plasma $\left(0 \cdot 96 \pm 0.2 \times 10^{9} / \mathrm{M}, n=6\right)$. Binding capacity $\left(\mathrm{B}_{\max }\right)$ values increased from nondetectable levels in animals aged 25-38 days post-partum to reach concentrations around half that seen in the adult $\left(1 \cdot 4 \pm 0 \cdot 2 \times 10^{-9} \mathrm{M}\right)$ by about 117 days post-partum and remained at this level until 153 days post-partum. Therefore, in early pouch life when plasma GH concentrations are highest, the very low concentrations of GHBP are unlikely to be important in terms of competing with GH-receptor for ligand or altering the half-life of circulating $\mathrm{GH}$.

Journal of Endocrinology (2002) 173, 507-515

\section{Introduction}

Marsupials are born at an immature stage of physical development after a short gestation and their subsequent growth and development occurs in the pouch during a lengthy period of lactation (Tyndale-Biscoe 1973). Organ systems necessary for the young to breathe, ingest milk, crawl in a directional manner and respond to some sensory inputs are well developed at birth as these are necessary for movement to the pouch and attachment to the teat (Gemmell \& Rose 1989, Janssens et al. 1997). Further development and growth continues during pouch life but little is known of the hormones and growth factors that regulate these processes in marsupials. During pouch life, apart from synthesis by the young itself, milk is the only possible source of hormones and growth factors.

In eutherian mammals, growth hormone $(\mathrm{GH})$ is an important regulator of postnatal growth and development, although its role during fetal life remains unclear. It is also involved in a number of anabolic processes including the stimulation of protein and nucleic acid synthesis and the maintenance of lipid, carbohydrate, nitrogen and mineral metabolism (Kawauchi \& Yasuda 1989). GH mediates its actions on target tissues by interacting with a membranebound GH-receptor (GHR). In plasma, GH has been shown to form a complex with growth hormone-binding proteins (GHBPs) (Baumann et al. 1986, Herington et al. 1986). GHBPs have been identified in a number of species, including the human (Herington et al. 1986), rabbit (Spencer et al. 1988), mouse (Smith et al. 1989), rat (Baumbach et al. 1989), cow (Devolder et al. 1993) and chicken (Vasilatos-Younken et al. 1991). In the human and several other species, at least two forms of GHBP have been shown to exist: a high affinity, low capacity binding protein (Baumann et al. 1986, Herington et al. 1986) and a low affinity, high capacity binding protein (Baumann \& 
Shaw 1990). The high affinity GHBP is identical to the extracellular domain of the membrane-bound GHR (Leung et al. 1987) and is formed by either alternative splicing of the GHR gene (Baumbach et al. 1989, Smith et al. 1989, Martini et al. 1997) or proteolytic cleavage of the extracellular domain of the GHR (Leung et al. 1987, Sotiropoulos et al. 1993). GHBPs have been shown to modify the cellular actions of $\mathrm{GH}$ by altering its in vivo kinetics and metabolism (Baumann et al. 1987, Veldhuis 1993) and by competing with receptors for ligand (Lim et al. 1990, Mannor et al. 1991). In addition, circulating levels of GHBP in the rabbit, pig and rat have been shown to reflect GHR concentrations in target tissues (Mulumba et al. 1991, Ambler et al. 1992, Ymer \& Herington 1992).

Given the important role GH plays in postnatal growth and development in eutherian mammals, GH is also likely to be important in the developing marsupial. The focus of this study was the brushtail possum (Trichosurus vulpecula). In this species a single, furless, physically immature young is born weighing $200 \mathrm{mg}$ and measuring approximately $15 \mathrm{~mm}$ after a gestation of $17 \cdot 5$ days (Pilton \& Sharman 1962). The young makes its first exit from the pouch at around 121 days post-partum (Dunnet 1956) and permanently leaves the pouch at around 150 days post-partum (Tyndale-Biscoe \& Renfree 1987), after it has acquired the ability to thermoregulate (Gemmell \& Cepon 1993). Weaning occurs between 180 and 210 days post-partum. The aim of this study was to examine, first, whether GHBP occurs in this species, and secondly, the changing pattern of plasma GH and GHBP during pouch life.

\section{Materials and Methods}

\section{Animals and collection of blood samples}

Blood samples were collected from brushtail possum adults and pouch young maintained in a breeding colony at the University of Queensland. These animals were kept in large outdoor enclosures and fed a variety of fresh fruits and vegetables, bread, oats, sultanas and dry dog feed (Drimeat Dog Ration, Provincial Traders Pty. Ltd, Brisbane, Queensland, Australia) and had access to water. The age of pouch young was either estimated from head length measurements according to a method described previously by Lyne and Verhagen (1957), or was known accurately ( \pm 3 days) from weekly pouch inspections conducted on adult female possums. Blood samples $(0 \cdot 2-$ $0.5 \mathrm{ml}$ ) were obtained by cardiac puncture from pouch young and adults that were lightly anaesthetized with a 3\% halothane (Rhone Merieux, West Footscray, Australia) in oxygen mixture $(0.5 \mathrm{l} / \mathrm{min})$. All samples were collected between 0800 and $0900 \mathrm{~h}$ and between April and December. Pouch young less than about 140 days postpartum were taken from the pouch whereas older pouch young were normally removed from their mother's back immediately before they were anaesthetised. All blood samples were centrifuged $\left(2000 \mathrm{~g}\right.$, for $10 \mathrm{~min}$ at $\left.4{ }^{\circ} \mathrm{C}\right)$ and the plasma fraction collected and stored at $-20{ }^{\circ} \mathrm{C}$ prior to being assayed for $\mathrm{GH}$ or GHBP. A permit for the collection and maintenance of possums was obtained from the Queensland Parks and Wildlife Service and experimental procedures were approved by the Animal Experimentation Ethics Committee of the University of Queensland.

\section{Collection of milk samples}

Milk samples were collected from female possums with pouch young aged between 12 and 150 days post-partum. Animals were anaesthetized as described above and the pouch young removed from the teat. Following an intracardiac injection of $0.1 \mathrm{ml}$ Syntocinon (synthetic oxytocin, $10 \mathrm{IU} / \mathrm{ml}$; Sandoz, Basel, Switzerland), the ejected milk was collected into capillary tubes and stored frozen at $-20{ }^{\circ} \mathrm{C}$ until assayed.

\section{Growth hormone radioimmunoassay}

Plasma and milk GH concentrations were determined in a heterologous radioimmunoassay (Curlewis \& McNeilly 1992). This assay uses an antiserum against wallaby $\mathrm{GH}$ (wGH) (G5/3; Curlewis \& McNeilly 1992) and brushtail possum $\mathrm{GH}(\mathrm{pGH})$ purified from pituitary glands (Curlewis \& McNeilly 1992) as standards. wGH (cWB-9) was used as the radioiodinated ligand and prepared using an iodogen method (Salacinski et al. 1981). All reagents

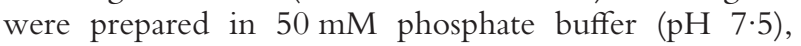
containing $0.15 \mathrm{M} \mathrm{NaCl}, 0.5 \%$ bovine serum albumin (BSA), and $0 \cdot 01 \% \mathrm{Na}$ azide. Standards $(0 \cdot 4-100 \mathrm{ng} / \mathrm{ml}$ in $50 \mu \mathrm{l})$, plasma $(2-50 \mu \mathrm{l})$ or milk $(50 \mu \mathrm{l})$ were made up to a total volume of $100 \mu \mathrm{l}$ and incubated with $100 \mu \mathrm{l}$ G5/3 antibody $\left(1 / 5000\right.$ initial dilution) overnight at $4{ }^{\circ} \mathrm{C}$. ${ }^{125}$ I-Labelled wGH $(15000-18000$ c.p.m. in $100 \mu \mathrm{l})$ was then added to the tubes and incubated at $4{ }^{\circ} \mathrm{C}$ overnight. On day three, $100 \mu \mathrm{l}$ donkey anti-guinea-pig serum ( 1 in 20 dilution) and $100 \mu \mathrm{l}$ normal guinea pig serum (1/200 dilution) were added and once again incubated overnight at $4{ }^{\circ} \mathrm{C}$. Bound hormone was precipitated with $2 \mathrm{ml} 3 \%$ polyethylene glycol (PEG) 6000/0.9\% saline and centrifuged at 2500 r.p.m. for $30 \mathrm{~min}\left(4^{\circ} \mathrm{C}\right)$, before decanting and counting radioactivity in the precipitated pellet. Radioactive counts were analysed by the AssayZap computer program (Biosoft, Cambridge, UK), which generates standard curves using a weighted four-parameter fit and determines concentration values. Inter- and intraassay coefficients of variation were $18.0 \%$ (for plasma $\mathrm{GH}$ concentrations between 6 and $17 \mathrm{ng} / \mathrm{ml}$ ) and $3.5 \%$ (at concentrations between 3.5 and $9.6 \mathrm{ng} / \mathrm{ml}$ ) respectively and the assay sensitivity was $0.8 \mathrm{ng} / \mathrm{ml}$. Addition of $\mathrm{pGH}$ $(1.6-12.5 \mathrm{ng})$ to possum plasma from two individuals 
resulted in a recovery of $97 \pm 3 \%$ (S.E.M) and $100 \cdot 2 \pm 3 \%$ (S.E.M). Addition of pGH $(1 \cdot 6-12 \cdot 5 \mathrm{ng})$ to possum milk resulted in a recovery of $96 \pm 9 \%$ (S.E.M).

\section{GHBP - gel filtration method}

To demonstrate the presence of GHBP in possum plasma, a gel filtration method similar to that described previously by Baumann et al. (1986) was used. This method was validated using both adult possum and human plasma (Saunders 2000). Monomeric, ${ }^{125}$ I-radiolabelled recombinant human GH ( ${ }^{125} \mathrm{I}-\mathrm{hGH} ; 100000$ c.p.m.), radiolabelled using an iodogen method (Salacinski et al. 1981), and plasma $(1 \mathrm{ml})$ were made up to $1.2 \mathrm{ml}$ with phosphate-buffered saline (PBS; pH 7.4) and BSA (0.5\%). This reaction was incubated for $1 \mathrm{~h}$ at $37^{\circ} \mathrm{C}$, before being placed on ice and then loaded onto a Superdex $75 \mathrm{Hr}$ 10/30 column (Pharmacia Biotech, Uppsala, Sweden) which had been equilibrated at room temperature with PBS containing $0 \cdot 01 \%$ BSA. Fractions $(1 \cdot 2$ or $1.4 \mathrm{ml})$ were collected and the radioactivity contained within the fractions determined in a $\gamma$-counter. Additional reactions containing ${ }^{125} \mathrm{I}-\mathrm{hGH}$ alone and ${ }^{125} \mathrm{I}-\mathrm{hGH}$ plus excess GH (human or possum) were incubated as described above prior to gel filtration to indicate whether binding to plasma was displaceable. To determine the molecular weight (MW) of compounds eluting from the column, a mixture of calibration standards was separated on the column and peaks identified by UV detection. The calibration standard mix (Sigma, St Louis, MO, USA) contained $0 \cdot 2 \mathrm{mg}$ Dextran Blue (MW $\left.2 \times 10^{6}\right), 0 \cdot 8 \mathrm{mg}$ BSA (MW 66000 ), $0.8 \mathrm{mg}$ carbonic anhydrase (MW 29000 ) and $0.4 \mathrm{mg}$ cytochrome C (MW 12 400).

\section{GHBP - immunoprecipitation method}

An immunoprecipitation method, described previously by Barnard et al. (1989), was used to determine the binding affinity $\left(K_{\mathrm{a}}\right)$ and capacity $\left(\mathrm{B}_{\max }\right)$ of GHBP in the plasma of adult and developing brushtail possums. This assay utilizes monoclonal antibody 43 (Mab 43) which recognizes the rabbit GHBP and GHR and has been shown to precipitate GHBP in the plasma of humans, rabbits and brushtail possums (Barnard et al. 1989, Saunders 2000). All possum plasma samples were diluted 1 in 8 in radioreceptor assay

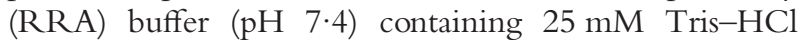

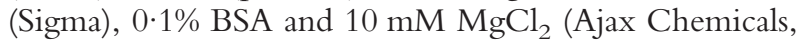
Auburn, Australia) to reduce endogenous GH below the level of interference in the immunoprecipitation assay (Ho et al. 1993). For the pouch young, it was necessary to pool plasma from several individuals in order to provide sufficient sample for the assay. Equal plasma volumes from each of six individuals was used for each of the following age groups: $25-38,45-54,73-87,117-124$ and 144-153 days post-partum. The assay was repeated on two separate plasma pools for each age group. Duplicate or triplicate plasma samples $(100 \mu \mathrm{l})$ of adult and pouch young plasma were incubated with increasing concentrations of recombinant hGH $(0-10000 \mathrm{ng})$ and ${ }^{125} \mathrm{I}-\mathrm{hGH}$ $(\approx 100000$ c.p.m.) in a total volume of $500 \mu \mathrm{l} \mathrm{RRA}$ buffer. After $1 \mathrm{~h}$ at room temperature, $100 \mu \mathrm{l}$ MAb 43 (1 in 250 dilution) were added to the tubes before incubation at $4{ }^{\circ} \mathrm{C}$ overnight. The following day, the antibody-bound complex was precipitated by adding $1 \mathrm{ml} 0.1 \%$ bovine $\gamma$-globulin (Sigma) and $1 \mathrm{ml}$ 30\% PEG 6000. Tubes were left at $-20{ }^{\circ} \mathrm{C}$ for $30 \mathrm{~min}$ prior to centrifugation at 2800 r.p.m. $\left(25 \mathrm{~min} ; 4^{\circ} \mathrm{C}\right)$. Following centrifugation the supernatant was removed and the radioactivity was determined in a $\gamma$-counter. To determine that ${ }^{125} \mathrm{I}-\mathrm{hGH}$ binding was comparable between assays, MAb 43 binding to rabbit serum in the presence and absence of excess hGH $(1 \mu \mathrm{g})$ was used as a quality control. A single plasma sample assayed in duplicate, four times within a single assay, provided within assay coefficients of variation for $K_{\mathrm{a}}$ and $\mathrm{B}_{\max }$ values. These were $26 \cdot 4 \%$ and $23 \cdot 7 \%$ respectively.

$K_{\mathrm{a}}$ and $\mathrm{B}_{\max }$ values for GHBP in possum plasma were determined by Scatchard analysis (Scatchard 1949). Scatchard analysis and line fitting (weighted non-linear least squares method) were carried out using the EBDA and LIGAND programs respectively (Biosoft Corporation).

\section{Statistics}

A method described by Janssens et al. (1990) was used to define the plasma profile of $\mathrm{GH}$ in pouch young in terms of a simple exponential decline equation. The statistical package PRISM (GraphPad Software, San Diego, CA, USA) was used to fit the equation using a non-linear, least squares method. Plasma GH data for pouch young were also grouped into 25-day age groupings so that means and standard errors could be determined. Log-transformed data for the seven age groups $(20-45,46-70,71-95,96-120$, 121-145, 146-170 and 171-200 days post-partum) and adults were then compared using one-way analysis of variance (ANOVA) followed by Dunnett's New Multiple Range test to compare individual means. Unpaired $t$-tests were used to compare mean GH and GHBP $K_{\mathrm{a}}$ and $\mathrm{B}_{\max }$ values between adult males and females. ANOVA, $t$-tests and linear regression were performed using INSTAT software (San Diego, CA, USA).

\section{Results}

\section{Plasma and milk GH concentrations}

Plasma GH concentrations in pouch young were highest early in pouch life and thereafter declined in an exponential fashion (Fig. 1A). Mean data at each age were fitted to the equation $\mathrm{y}=\left(\mathrm{A}+\mathrm{Be}^{(-\mathrm{D} \times \mathrm{Age})}\right)$ to provide estimates of A (asymptotic GH concentration), B and D (constants). 


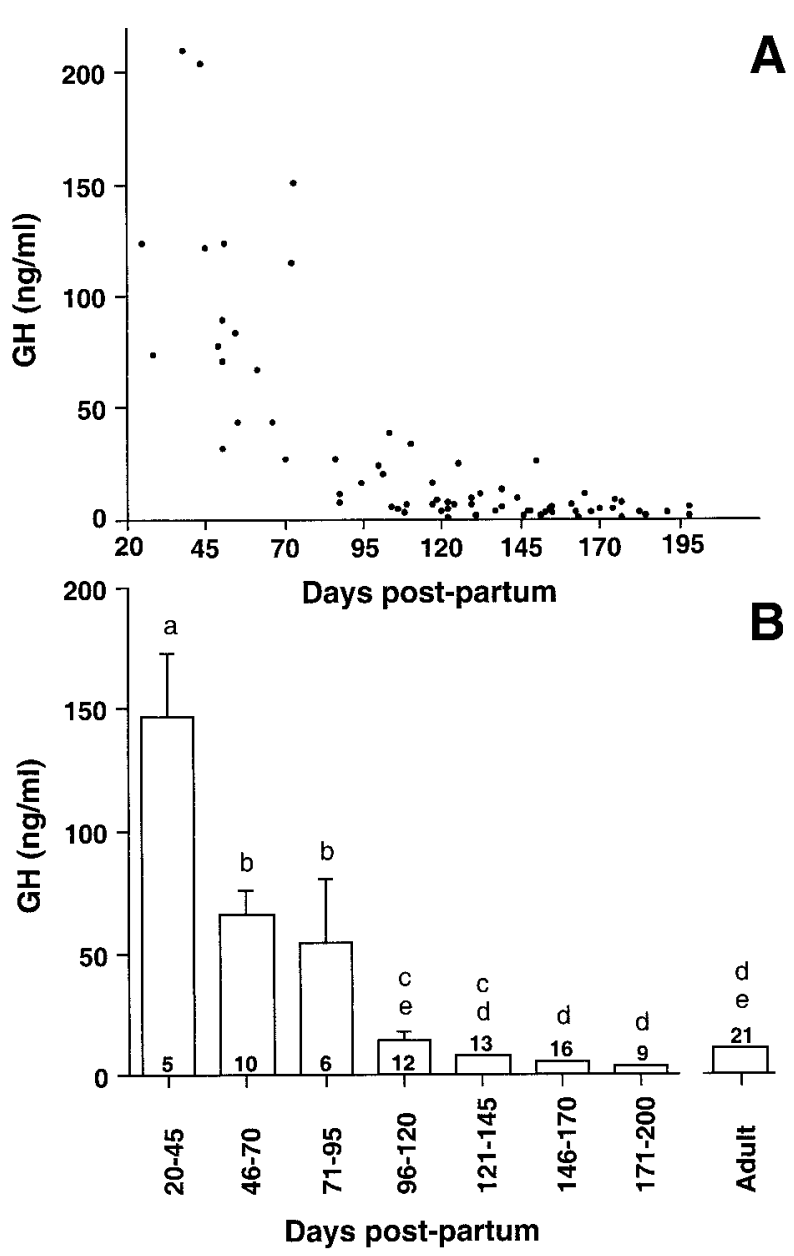

Figure $1 \mathrm{GH}$ concentrations in plasma samples from possum pouch young aged 25 to 198 days post-partum $(n=71)$ and adults $(n=21)$. Data shown as $(\mathrm{A})$ individual data for pouch young or (B) grouped according to post-partum age (means \pm S.E.M.). The number of animals within each category is shown within or above the histogram bars. Groups with the same letters are not significantly different $(P>0 \cdot 05)$.

These were $-11.99,268$ and 0.01849 respectively $\left(r^{2}=0.67 ; P<0 \cdot 001\right)$. Plasma GH values from the same pouch young were also grouped into 25 -day age groupings so that means and standard errors could be determined (Fig. 1B). One-way ANOVA revealed a highly significant $(P<0.001)$ effect of age. At $20-45$ days post-partum, GH concentrations were significantly $(P<0 \cdot 05)$ greater than at any other age and at 46-70, 71-95 and 96-120 days post-partum, the concentrations of GH were still significantly $(P<0 \cdot 05)$ greater than those in pouch young aged 171-200 days post-partum. GH concentrations in the groups aged between 121 and 200 days were not significantly different from each other. Plasma GH concentrations in adult male $(8 \cdot 4 \pm 2 \cdot 3 \mathrm{ng} / \mathrm{ml} ; n=5)$ and female $(11.5 \pm 2.2 \mathrm{ng} / \mathrm{ml} ; n=16)$ possums were not significantly
$(P>0 \cdot 1)$ different so values for all adults were pooled and compared with those in pouch young. Before 95 days post-partum, GH concentrations in pouch young were significantly greater than those in adult possums $(P<0 \cdot 01)$. $\mathrm{GH}$ could not be detected in any milk sample.

\section{GHBP - gel filtration method}

The gel filtration profile in Fig. 2A shows that three ${ }^{125}$ I-labelled GH-related peaks could be identified in adult possum plasma, in addition to a free iodine peak which eluted at approximately $150 \mathrm{ml}$ (determined separately with ${ }^{125} \mathrm{INa}$ ). The three GH-related peaks eluted in the void volume (peak 1 ) and at approximately 50 (peak 2) and $73 \mathrm{ml}$ (peak 3). Based on the elution profile of the calibration standards peaks 2 and 3 had molecular masses of approximately 85 and $21 \mathrm{kDa}$ respectively. The $21 \mathrm{kDa}$ peak was identified as monomeric hGH because this peak of radioactivity was seen with ${ }^{125} \mathrm{I}-\mathrm{hGH}$ alone (Fig. 2C). Peak 2 binding was readily displaced by excess hGH $(20 \mu \mathrm{g})$ and partially displaced by excess pGH $(20 \mu \mathrm{g})$, while peak 1 binding was not displaced by either human or possum GH (Fig. 2B).

Chromatography of recombinant human GHBP (100 ng; gift of Genentech Inc, San Francisco, CA, USA) in the presence of ${ }^{125} \mathrm{I}-\mathrm{hGH}$ confirmed that peak 2 binding seen in the presence of plasma corresponded to the size expected for ${ }^{125}$ I-labelled hGH binding to a high affinity GHBP (Fig. 3B). When compared with the elution profile for possum plasma (Fig. 3A) the profiles were identical except for the presence in plasma of the void volume peak (peak 1).

\section{GHBP - immunoprecipitation method}

${ }^{125}$ I-Labelled hGH binding was readily displaced with increasing amounts of unlabelled hGH in adult possum plasma (Fig. 4A). Displacement curve data were subsequently used in Scatchard analysis (Fig. 4B) to determine the $K_{\mathrm{a}}$ and $\mathrm{B}_{\max }$ values for GHBP in adult possum plasma. The $K_{\mathrm{a}}$ value for adult male possums $\left(0.63 \pm 0.1 \times 10^{9} /\right.$ $\mathrm{M} ; n=3)$ was not significantly different to that of females $\left(1 \cdot 3 \pm 0.3 \times 10^{9} / \mathrm{M} ; n=3\right)(P>0 \cdot 1 ;$ Fig. $4 \mathrm{C})$. However, the $B_{\max }$ value for males $\left(1.8 \pm 0.1 \times 10^{-9} \mathrm{M}\right)$ was significantly greater than that of female possums $\left(0 \cdot 9 \pm 0 \cdot 3 \times 10^{-9} \mathrm{M}\right)(P<0 \cdot 05$; Fig. $4 \mathrm{D})$.

$K_{\mathrm{a}}$ and $\mathrm{B}_{\max }$ values for GHBP were also determined in pouch young plasma (Fig. 5). Specific binding could not be detected in the 25- to 38-day-old pools. With the exception of one of the plasma pools in the 45-54 day age group, $K_{\mathrm{a}}$ values were relatively constant throughout pouch life and varied between 1.0 and $2.4 \times 10^{9} / \mathrm{M}$, which was slightly higher than that in adult plasma $\left(0.96 \pm 0.2 \times 10^{9} / \mathrm{M}, n=6\right.$; Fig. $\left.5 \mathrm{~A}\right)$. In contrast, $\mathrm{B}_{\max }$ values increased with age of the pouch young as indicated by a significant $\left(P<0 \cdot 001, \mathrm{r}^{2}=0 \cdot 86\right)$ linear regression. $\mathrm{B}_{\max }$ 


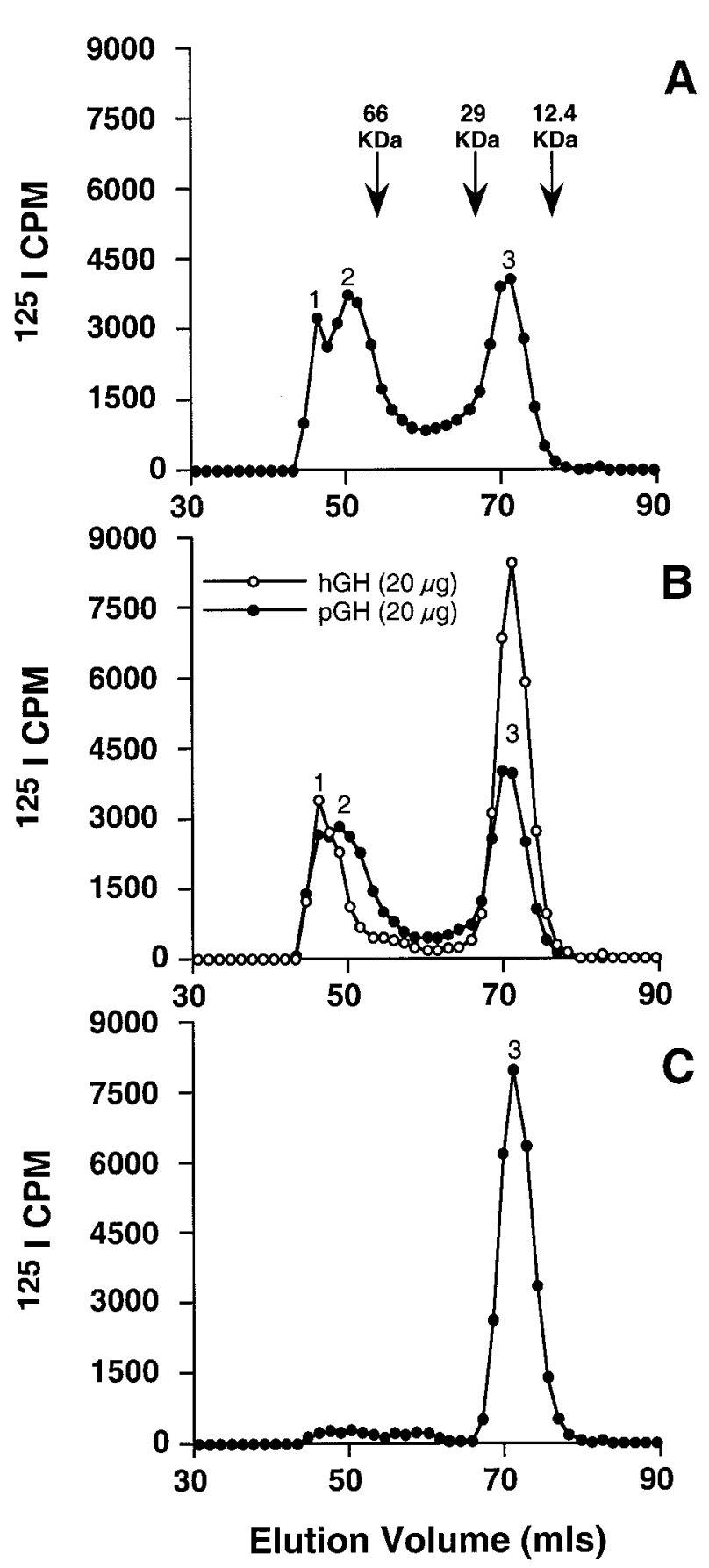

Figure 2 Gel filtration profiles for ${ }^{125} \mathrm{I}-\mathrm{hGH}$ incubated with (A) adult possum plasma $(1 \mathrm{ml}),(B)$ adult possum plasma + excess $\mathrm{GH}(20 \mu \mathrm{g}$ human $\mathrm{GH}$ or possum $\mathrm{GH})$ or $(\mathrm{C})$ buffer. 1, 2 and 3 indicate the radioactive peaks referred to in the text.

values were lowest in the 45-54 and 73-87 day pools then increased three- to fourfold by 117-124 days post-partum with no further increase in the 144-153 day pools. $\mathrm{B}_{\max }$ values for the 117-153 day pouch young remained below
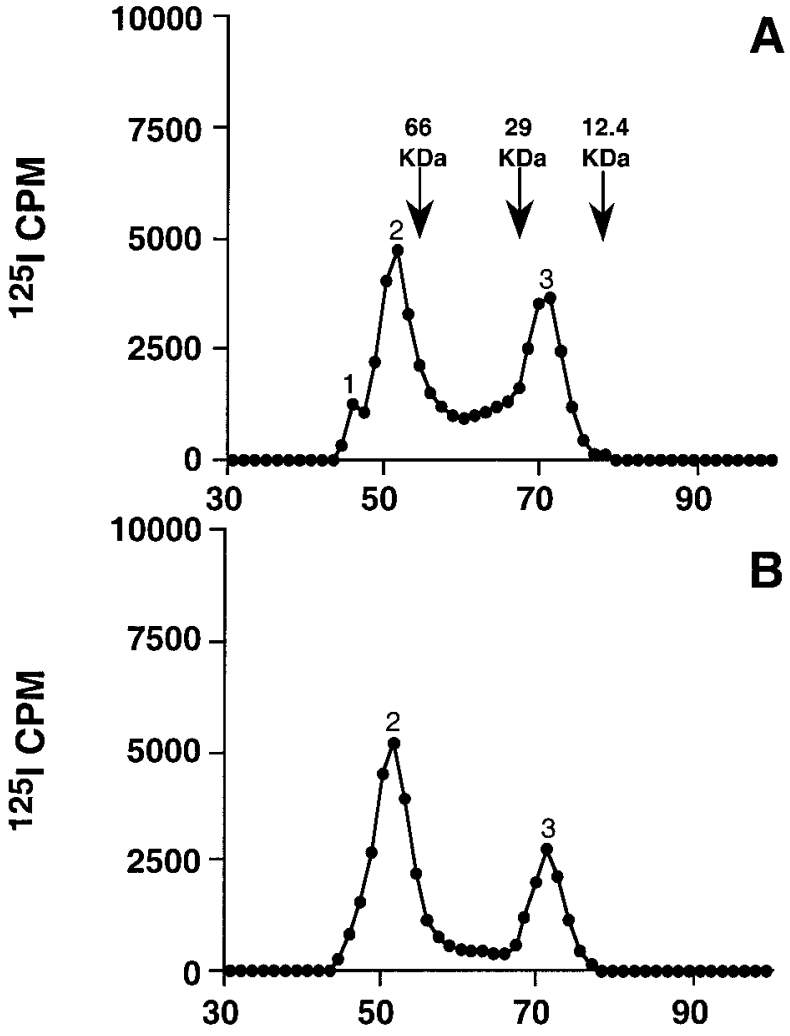

\section{Elution Volume (m/s)}

Figure 3 Gel filtration profiles for ${ }^{125} \mathrm{I}-\mathrm{hGH}$ incubated with (A) adult possum plasma or (B) purified recombinant human GHBP (100 ng). 1, 2 and 3 indicate the radioactive peaks referred to in the text.

the 95\% confidence interval calculated from adult plasma $(n=6$; Fig. $5 \mathrm{~B}$; pooled male and female data from Fig. 4).

\section{Discussion}

In this, the first detailed study of both GH and GHBP in the plasma of a marsupial pouch young, we have characterized a high affinity GHBP, of similar MW to that in eutherian mammals, and shown that plasma concentrations of GHBP are below the level of detection in the first month of pouch life. They then gradually increase to about half that in the adult by 120 days post-partum, which is about the time the young makes its first exit from the pouch, and remain at this level until 150 days post-partum. In contrast, plasma $\mathrm{GH}$ concentrations are initially high and then decline to reach adult concentrations by approximately 121-145 days post-partum. Despite its more rapid rate of development (Russell 1982), the marsupial bandicoot (Isoodon macrourus) shows a similar plasma GH 

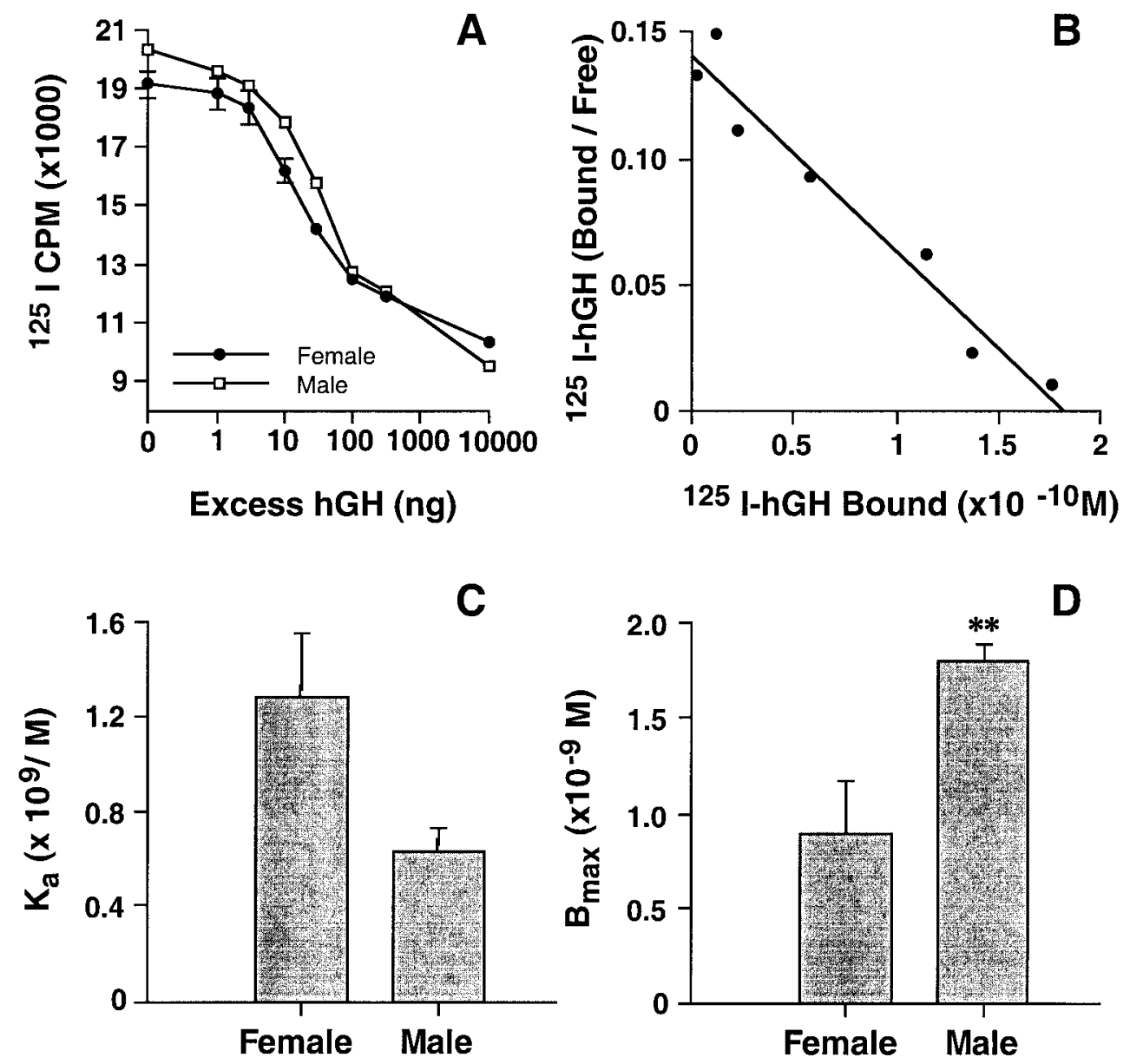

Figure $4{ }^{125} \mathrm{I}-\mathrm{hGH}$ binding in adult possum plasma. (A) Displacement curves determined in the presence of increasing concentrations of unlabelled hGH for female $(n=3)$ and male $(n=3)$ possums. (B) Representative Scatchard plot of ${ }^{125} \mathrm{I}$-hGH binding to possum GHBP. (C) $K_{\mathrm{a}}$ and (D) $B_{\max }$ estimates of GHBP in plasma from female $(n=3)$ and male $(n=3)$ possums. Values represent means \pm S.E.M. ${ }^{* *} P<0.05$ compared with female values.

profile during pouch life with a corresponding earlier decline in GH to adult-like levels (Saunders et al. 2000).

Ultrastructural and immunohistochemical evidence show that the pituitary gland of the newborn marsupial is capable of synthesis and secretion of GH (Leatherland \& Renfree 1983, Walker \& Gemmell 1983, Gemmell \& Nelson 1988). Further, with the radioimmunoassay used in the present study, GH could be detected in the head of newborn pouch young (11 ng/head), and by day 12 post-partum the pituitary gland content was $0.75 \pm 0.21 \mu \mathrm{g}$ (Saunders 2000). Given that GH could not be detected in possum milk, it seems likely that the high plasma GH during early pouch life comes from the anterior pituitary gland. Very high plasma GH concentrations also occur during development of eutherian mammals but these peak in utero. For example, human and sheep fetuses have elevated GH concentrations that are well in excess of adult GH concentrations. For humans, a major decline in $\mathrm{GH}$ concentrations then occurs mid-gestation (Gluckman et al. 1981) while for sheep it occurs around the time of parturition (Bassett et al. 1970, Gluckman et al. 1981). In contrast, in the rat GH concentrations increase rapidly during late gestation, peak at birth and then decline over the next ten days (Rieutort 1974). This decline in plasma GH levels in fetal and neonatal eutherians appears to be associated with key developmental or maturational changes such as the onset of inhibitory control by somatostatin, decreased secretion of GH-releasing hormone (Gluckman et al. 1979) and the development of the negative feedback mechanism, where increasing insulin-like growth factor-I (IGF-I) concentrations act directly on the pituitary gland to decrease GH secretion (Arosio et al. 1995). The decline in plasma $\mathrm{GH}$ in marsupials is also likely to reflect maturation of the 


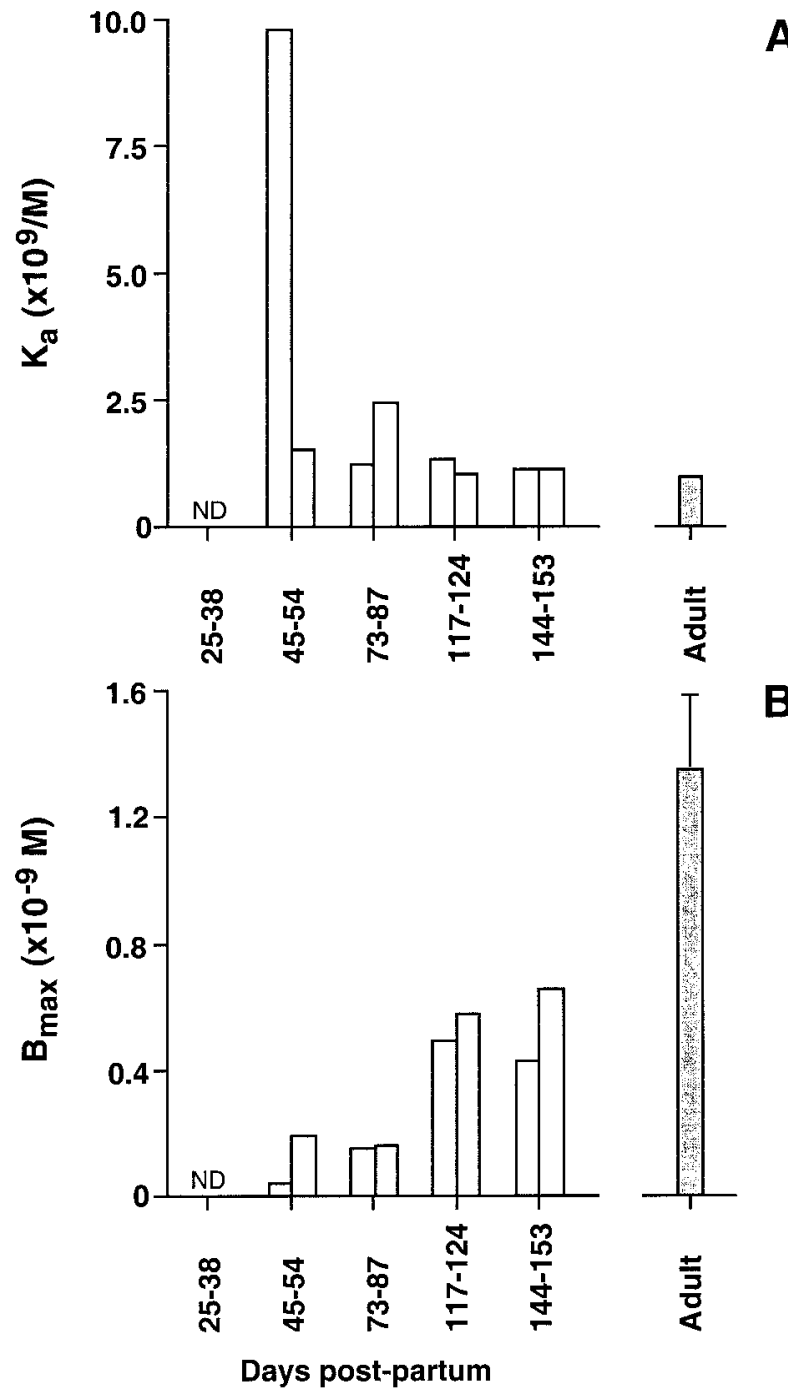

Figure 5 GHBP in pouch young plasma. (A) $K_{a}$ and (B) $B_{\max }$ were determined on two independent plasma pools for each age group with each pool comprised of plasma from 6 animals. ND, below the limit of detection. Adult $K_{\mathrm{a}}$ and $\mathrm{B}_{\max }(n=6$; means \pm S.E.M. $)$ are pooled male and female values from Fig. 4.

$\mathrm{GH}$ axis. For example, in related research, we have shown that liver gene expression of two key components of the GH axis, GHR and IGF-I, is low during early pouch life when plasma GH levels are high but has significantly increased by 125 days post-partum, which coincides with the final suppression of $\mathrm{GH}$ to low concentrations (Saunders 2000).

Gel filtration experiments revealed that possum plasma contained a high affinity GHBP with a molecular mass of approximately $65 \mathrm{kDa} .{ }^{125} \mathrm{I}-\mathrm{hGH}$ binding to this protein was readily displaced by excess non-labelled hGH but was only partially displaced by pGH. The bioactivity of this pituitary-derived $\mathrm{pGH}$ has not been tested but it is not uncommon for such preparations to be immunoreactive but not bioactive, which would account for its failure to completely displace ${ }^{125} \mathrm{I}-\mathrm{hGH}$ bound to GHBP. A similar gel filtration profile to that obtained with possum plasma and ${ }^{125} \mathrm{I}-\mathrm{hGH}$ was also evident when recombinant human GHBP and ${ }^{125} \mathrm{I}-\mathrm{hGH}$ were run on the column. This confirmed that the protein in possum plasma was similar in size to that of the high affinity GHBP $(63 \mathrm{kDa})$ present in the human (Baumann et al. 1986, Herington et al. 1986), pig (Davis et al. 1992) and rabbit (Spencer et al. 1988), but was substantially smaller than that in rat serum (110 kDa: Massa et al. 1990). In the presence of possum plasma, an additional radioactive peak eluted in the void volume of the column. This peak was not present when ${ }^{125} \mathrm{I}-\mathrm{hGH}$ alone or recombinant human GHBP and ${ }^{125} \mathrm{I}-\mathrm{hGH}$ were run on the column, and was not displaced by excess GH. This large MW product is likely to be either a low affinity GHBP like that described by Baumann and Shaw (1990) or some multimeric form of the high affinity GHBP.

The ${ }^{125} \mathrm{I}-\mathrm{hGH}$ binding/immunoprecipitation assay and subsequent Scatchard analysis revealed that possum GHBP bound ${ }^{125} \mathrm{I}-\mathrm{hGH}$ with a high affinity and low capacity, similar to that seen in eutherian mammals. The monoclonal antibody used in this assay (Mab 43) is specific for the extracellular domain of the GHR (Barnard \& Waters 1986), therefore providing further evidence that GHBP is a plasma protein in this species. $K_{\mathrm{a}}$ values for possum GHBP were similar between male and female possums and to those obtained for the human (possum: $K_{\mathrm{a}}=0.96 \pm$ $0.2 \times 10^{9} / \mathrm{M}$, present study; human: $K_{\mathrm{a}}=0 \cdot 9 \pm 0 \cdot 1 \times$ $10 \%$ M, Barnard et al. 1989). However, based on a very small number of animals, $B_{\max }$ values for possum GHBP were significantly different between the sexes, with concentrations higher in males than females.

Scatchard analysis of GHBP in pouch young plasma showed that throughout pouch life the $K_{\mathrm{a}}$ of GHBP did not vary markedly. $K_{\mathrm{a}}$ values could not be determined in the youngest age group (25-38 days post-partum) as ${ }^{125} \mathrm{I}-\mathrm{hGH}$ binding was extremely low. For the older age groups (over 45 days post-partum), $K_{\mathrm{a}}$ values were slightly higher than those obtained for the adult possum $\left(0 \cdot 96 \pm 0.2 \times 10^{9} / \mathrm{M}\right)$. In contrast, $\mathrm{B}_{\max }$ values did change throughout pouch life with binding capacity increasing from non-detectable levels (25-38 days post-partum) to about half that observed in the adult possum by around 117 days post-partum. An increase in GHBP levels with age, like that seen in the possum, is also evident in the human, rat and pig (Daughaday et al. 1987, Baumann et al. 1989, Mulumba et al. 1991, Ambler et al. 1992). In the human, GHBP levels increase from low levels in the fetus and neonate to reach peak levels between 20 and 46 years of age and thereafter decline (Daughaday et al. 1987). Studies on rats and pigs have also shown that circulating concentrations of GHBP are positively correlated with hepatic GHR levels (Mulumba et al. 1991, Ambler et al. 
1992) and indeed we have also shown that liver GHR gene expression in possum pouch young is low early in pouch life but increases by 125 days post-partum therefore correlating with the increased GHBP reported here (Saunders 2000).

In summary, this study shows that plasma GH concentrations in the brushtail possum pouch young are high during early pouch life and then decline so that by the time the young makes its first exit from the pouch, plasma levels are similar to those in the adult. In addition, this study shows that plasma concentrations of GHBP increase from non-detectable levels in early pouch life to be about half those in the adult at the time of first pouch exit. Similar changes in plasma GH and GHBP also occur in eutherian mammals, either during gestation or soon after parturition when eutherian species are at similar stages of development to the marsupial young when it makes its first exit from the pouch. These results for a marsupial are in accord with the notion that the timing of these endocrine changes is associated with developmental or maturational changes rather than external influences from the placenta or parturition per se.

\section{Acknowledgements}

The authors would like to thank Dr Lyn Hinds for supplying donkey anti-guinea-pig serum used in the GH radioimmunoassay. This research was funded in part by the Australian Research Council (through grants to R T G and J D C).

\section{References}

Ambler GR, Breier BH, Surus A, Blair HT, McCutcheon SN, Silbergeld A \& Gluckman PD 1992 The interrelationship between and the regulation of hepatic growth hormone receptors and circulating GH binding protein in the pig. Acta Endocrinologica 126 $155-161$.

Arosio M, Cortelazzi D, Persani L, Palmieri E, Casati G, Baggiani AM, Gambino G \& Beck-Peccoz P 1995 Circulating levels of growth hormone, insulin-like growth factor-I and prolactin in normal, growth retarded and anencephalic human fetuses. Journal of Endocrinological Investigation 18 346-353.

Barnard R \& Waters MJ 1986 Serum and liver cytosolic growth hormone-binding proteins are antigenically identical with liver membrane 'receptor' types 1 and 2. Biochemical Journal 237 885-892.

Barnard R, Quirk P \& Waters MJ 1989 Characterization of the growth hormone-binding protein of human serum using a panel of monoclonal antibodies. Journal of Endocrinology 123 327-332.

Bassett JM, Thorburn GD \& Wallace ALC 1970 The plasma growth hormone concentration of the foetal lamb. Journal of Endocrinology 48 251-263.

Baumann G \& Shaw MA 1990 A second, lower affinity growth hormone-binding protein in human plasma. Journal of Clinical Endocrinology and Metabolism 70 680-686.

Baumann G, Stolar MW, Amburn K, Barsano CP \& Devries BC 1986 A specific growth hormone-binding protein in human plasma: initial characterisation. Journal of Clinical Endocrinology and Metabolism 62 134-141.
Baumann G, Amburn K \& Buchanan TA 1987 The effect of circulating growth hormone-binding protein on metabolic clearance, distribution and degradation of human growth hormone. Journal of Clinical Endocrinology and Metabolism 64 657-660.

Baumann G, Shaw MA \& Amburn K 1989 Regulation of plasma growth hormone-binding proteins in health and disease. Metabolism 38 683-689.

Baumbach WR, Horner DL \& Logan JS 1989 The growth hormonebinding protein is an alternatively spliced form of the rat growth hormone gene. Genes and Development 3 1199-1205.

Curlewis JD \& McNeilly AS 1992 Purification, partial characterisation, and radioimmunoassay of prolactin and growth hormone from the Bennett's wallaby. General and Comparative Endocrinology 88 341-350.

Daughaday WH, Trivedi B \& Andrews BA 1987 The ontogeny of serum GH binding protein in man: a possible indicator of hepatic GH receptor development. Journal of Clinical Endocrinology and Metabolism 65 1072-1074.

Davis SL, Graf M, Morrison CA, Hall TR \& Swift PJ 1992 Identification and partial purification of serum growth hormone binding protein in domestic animal species. Journal of Animal Science $70773-780$.

Devolder A, Renaville R, Sneyers M, Callebaut I, Massart S, Goffinet A, Burny A \& Portetelle D 1993 Presence of growth hormonebinding proteins in cattle plasma and milk. Journal of Endocrinology 138 91-98.

Dunnet GM 1956 A live-trapping study of Australian brush-tailed possums, Trichosurus vulpecula Kerr (Marsupialia). CSIRO Wildlife Research 1 1-18.

Gemmell RT \& Nelson J 1988 The ultrastructure of the pituitary and the adrenal gland of three newborn marsupials (Dasyurus hallucatus, Trichosurus vulpecula, Isoodon macrourus). Anatomy and Embryology 177 395-402.

Gemmell RT \& Rose RW 1989 Organ development in some newborn marsupials with particular reference to the rat kangaroos. In Kangaroos, Wallabies and Rat Kangaroos, pp 349-354. Eds I Hume \& G Grigg. Sydney: Australian Mammal Society and Surrey Beatty and Sons.

Gemmell RT \& Cepon G 1993 The development of thermoregulation in the marsupial brushtail possum Trichosurus vulpecula. Comparative Biochemistry and Physiology A 106 167-173.

Gluckman PD, Mueller PL, Kaplan SL, Rudolph AM \& Grumbach MM 1979 Hormone ontogeny in the ovine fetus. III. The effect of exogenous somatostatin. Endocrinology 104 974-978.

Gluckman PD, Grumbach MM \& Kaplan SL 1981 The neuroendocrine regulation and function of growth hormone and prolactin in the mammalian fetus. Endocrine Reviews $\mathbf{2}$ 363-395.

Herington AC, Ymer S \& Stevenson J 1986 Identification and characterisation of specific binding proteins for growth hormone in normal human sera. Journal of Clinical Investigation $\mathbf{7 7}$ $1817-1823$

Ho KK, Valiontis E, Waters MJ \& Rajkovic IA 1993 Regulation of growth hormone binding protein in man: comparison of gel chromatography and immunoprecipitation methods. Journal of Clinical Endocrinology and Metabolism 76 302-308.

Janssens PA, Grigg JA, Dove H \& Hulbert AJ 1990 Thyroid hormones during development of a marsupial, the tammar wallaby, Macropus engenii. Journal of Endocrinology 127 427-436.

Janssens PA, Hulbert AJ \& Baudinette RV 1997 Development of the pouch young from birth to pouch vacation. In Marsupial Biology: Recent Research, New Perspectives, pp 71-87. Eds NR Saunders \& LA Hinds. Sydney: University of New South Wales Press Ltd, Australia.

Kawauchi H \& Yasuda A 1989 Evolutionary aspects of growth hormones from nonmammalian species. In Advances in Growth 
Hormone and Growth Factor Research, pp 51-68. Eds EE Muller, D Cocchi \& V Locatelli. Roma-Milano and Berlin-Heidelberg: Pythagora Press and Springer Verlag.

Leatherland JF \& Renfree MB 1983 Structure of the pars distalis in pouch-young tammar wallabies (Macropus engenii). Cell and Tissue Research 230 587-603.

Leung DW, Spencer SA, Cachianes G, Hammonds RG, Collins C, Henzel WJ, Barnard R, Waters MJ \& Wood WI 1987 Growth hormone receptor and serum binding protein: purification, cloning and expression. Nature 330 537-543.

Lim L, Spencer SA, McKay P \& Waters MJ 1990 Regulation of growth hormone $(\mathrm{GH})$ bioactivity by a recombinant human GH-binding protein. Endocrinology 127 1287-1291.

Lyne AG \& Verhagen AMW 1957 Growth of the marsupial Trichosurus vulpecula and a comparison with some higher mammals. Growth 21 167-195.

Mannor DA, Winer LM, Shaw MA \& Baumann G 1991 Plasma growth hormone binding proteins: effect on growth hormone binding to receptors and on growth hormone action. Journal of Clinical Endocrinology and Metabolism 73 30-34.

Martini JF, Pezet A, Guezennec CY, Edery M, Postel-Vinay MC \& Kelly PA 1997 Monkey growth hormone (GH) receptor gene expression. Evidence for two mechanisms for the generation of the GH binding protein. Journal of Biological Chemistry 272 18951-18958.

Massa G, Mulumba N, Ketelslegers JM \& Maes M 1990 Initial characterization and sexual dimorphism of serum growth hormonebinding protein in adult rats. Endocrinology 126 1976-1980.

Mulumba N, Massa G, Ketelslegers JM \& Maes M 1991 Ontogeny and nutritional regulation of the serum growth hormone-binding protein in the rat. Acta Endocrinologica 125 409-415.

Pilton PE \& Sharman GB 1962 Reproduction in the marsupial Trichosurus vulpecula. Journal of Endocrinology 25 119-136.

Rieutort M 1974 Pituitary content and plasma levels of growth hormone in foetal and weanling rats. Journal of Endocrinology 60 261-268.

Russell EM 1982 Patterns of parental care and parental investment in marsupials. Biological Reviews 57 423-486.

Salacinski PRP, McLean C, Sykes JEC, Clement-Jones VV \& Lowry PJ 1981 Iodination of proteins, glycoproteins, and peptides using a

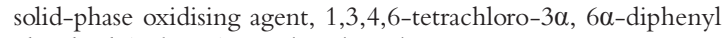
glycoluril (iodogen). Analytical Biochemistry 117 136-146.
Saunders MC 2000 Growth hormone in the developing and adult brushtail possum (Trichosurus vulpecula). $\mathrm{PhD}$ Thesis. University of Queensland, Brisbane, Australia.

Saunders MC, Gemmell RT \& Curlewis JD 2000 Plasma concentrations of thyroxine and growth hormone in the developing marsupial bandicoot (Isoodon macrourus). Reproduction, Fertility and Development 12 263-267.

Scatchard G 1949 The attraction of proteins for small molecules and ions. Annals of the New York Academy of Sciences 51 660-672.

Smith WC, Kuniyoski J \& Talamantes F 1989 Mouse serum growth hormone $(\mathrm{GH})$ binding protein has $\mathrm{GH}$ receptor extracellular and substituted transmembrane domains. Molecular Endocrinology 3 984-990.

Sotiropoulos A, Goujon L, Simonin G, Kelly PA, Postel-Vinay MC \& Finidori J 1993 Evidence for generation of the growth hormonebinding protein through proteolysis of the growth hormone membrane receptor. Endocrinology 132 1863-1865.

Spencer SA, Hammonds RG, Henzel WJ, Rodriguez H, Waters MJ \& Wood WI 1988 Rabbit liver growth hormone receptor and serum binding protein: purification, characterisation and sequence. Journal of Biological Chemistry 263 7862-7867.

Tyndale-Biscoe H 1973 Life of Marsupials. Melbourne: Edward Arnold.

Tyndale-Biscoe H \& Renfree M 1987 Reproductive Physiology of Marsupials. Cambridge: Cambridge University Press.

Vasilatos-Younken R, Andersen BJ, Rosebrough RW, McMurtry JP \& Bacon WL 1991 Identification of circulating growth hormonebinding proteins in domestic poultry: an initial characterisation. Journal of Endocrinology 130 115-122.

Veldhuis J, Johnson ML, Faunt LM, Mercado M \& Baumann G 1993 Influence of the high-affinity growth hormone (GH)-binding protein on plasma profiles of free and bound GH and on the apparent half-life of GH. Journal of Clinical Investigation 91 629-641.

Walker MT \& Gemmell RT 1983 Organogenesis of the pituitary, adrenal, and lung at birth in the wallaby, Macropus rufogriseus. American Journal of Anatomy 168 331-344.

Ymer S \& Herington AC 1992 Developmental expression of the growth hormone receptor gene in rabbit tissues. Molecular and Cellular Endocrinology 83 39-49.

Received 10 December 2001

Accepted 8 February 2002 